\title{
The Role of Education Level in the Intergenerational Pattern of Adolescent Pregnancy in Brazil
}

\begin{abstract}
CONTEXT: Adolescent pregnancy has been associated with the early childbearing experience of the mothers of adolescents, and young people's education level is believed to be an important factor in this phenomenon.
\end{abstract}

METHODS: In 2002, a representative household survey collected data from 3,050 young men and women aged 20-24 in three Brazilian cities. The main measures were mother's age at first birth, daughter's age at first pregnancy and son's age when he first impregnated a partner; ages were dichotomized as younger than 20 and 20 or older. The distribution of respondents by both their own and their mothers'reproductive experience was analyzed in relation to various characteristics, and logistic regressions assessed possible associations between these variables and pregnancy experience.

RESULTS: Thirty percent of women reported getting pregnant before age 20, and $21 \%$ of men said they were younger than 20 when they first impregnated a partner. Of these groups, 34\% of women and $31 \%$ of men reported that their mothers had first given birth at the same age. Both women and men were more likely to have had an early pregnancy experience if their mother had had a child before age 20 (odds ratios, 2.0 and 2.3, respectively). Among women, this positive association disappeared in the final model after adjusting for their education level, whereas among men the association remained after similar adjustment (1.8).

CONCLUSIONS: Daughters' and sons'level of education appears to be an important factor in the repetition of adolescent fertility across generations. Efforts are needed to increase access to education and to encourage young people to remain in school.

International Perspectives on Sexual and Reproductive Health, 2009, 35(3):139-146

\section{By Maria da Conceição Chagas de Almeida and Estela M.L.Aquino}

Maria da Conceição Chagas de Almeida is researcher, Gonçalo Moniz Research Center, Oswaldo Cruz Foundation, Salvador, Bahia, Brazil. Estela M.L. Aquino is associate professor, MUSAProgram of Gender and Health Studies, Institute of Collective Health, Federal University of Bahia, Salvador, Bahia, Brazil.
Adolescent pregnancy has been linked to the perpetuation of poverty across successive generations of women in a family, largely because it interrupts young women's schooling and reduces their chances of entering the job market. ${ }^{1-4}$ From a deterministic viewpoint, the underlying hypothesis is that the children of women who became pregnant as adolescents see early motherhood as the norm, and are more likely than others to follow their mother's model of early childbearing and to subsequently raise their own children in poverty.

In the early 1990s, Kahn and Anderson ${ }^{2}$ reviewed the U.S. literature and found that few studies had tested this hypothesis longitudinally, highlighting the inherent methodological difficulties of obtaining direct data from different generations. After analyzing data from the 1988 National Survey of Family Growth, these authors found a marked intergenerational pattern in which the daughters of women who had had their first child before age 20 were twice as likely as others to become teenage mothers. However, when this association was adjusted for variables that reflected the socioeconomic conditions in which these mothers had raised their daughters, the role of the mother's age at first birth diminished substantially.

In the same decade, Furstenberg et al. ${ }^{1}$ followed a cohort of U.S. children of black adolescent mothers over a 20-year period. They found an association between the mothers' age at first birth and their daughters' age at sexual initiation and at first pregnancy. Nevertheless, a large majority of second-generation men and women did not repeat the reproductive behavior of their mothers, and the authors attributed this in part to the legalization of abortion.

In the first decade of the 21st century, longitudinal studies ${ }^{5-8}$ conducted in various countries have attempted to identify factors involved in the repetition of early childbearing across generations; such factors could be used to develop public policies aimed at delaying childbearing until adulthood. In Brazil, the association between adolescent pregnancy and poverty has been widely accepted. ${ }^{9}$ The argument that adolescent childbearing contributes to school dropout, lower education levels, poorer job opportunities and consequently lower income levels has featured prominently in Brazilian studies. ${ }^{10-13}$

Traditionally, Brazilian women became pregnant at an early age and had large families; in recent decades, however several societal changes have influenced childbearingamong them, the wider availability of education, the greater participation of women in the job market and the increased use of contraceptive methods, which intensified in the 1960s. ${ }^{14}$ Since the 1970s, women's fertility has declined, especially among groups with the highest fertility rates: blacks, the poor, the least educated and those living in rural areas or in the north or northeastern region of the country. ${ }^{15}$ 
However, a so-called "rejuvenation of fertility" occurred in the 1990s, marked by absolute and relative growth in the mean number of children born to women aged 15-19. ${ }^{16}$

The impact of early childbearing on adolescents depends to a great extent on their socioeconomic status. For middleclass adolescents, having a child does not generally represent a disrupting factor in their life trajectory, although it may delay their academic careers. ${ }^{17}$ Among adolescents of lower socioeconomic status, the disruption is usually greater. ${ }^{9}$ However, recent studies have shown that factors other than childbearing also contribute to such disruption, and that about one in five of these adolescents leave school prior to becoming pregnant. ${ }^{18}$ In addition, young women are often already involved in childcare before giving birth themselves, and those in low-income households are socialized regarding the traditional roles of mothers and housewives, and hence help take care of the children in the family. Thus, having a child during adolescence may not constitute a "break in their daily routine of childcare." 19

Using data from Brazil's National Survey by Household Sampling, Rios-Neto et al. ${ }^{20}$ showed that the relationship between women's fertility and education level has changed over time. In 1983, 48\% of children aged 0-4 had mothers with low education levels. This proportion fell to $21 \%$ over the following 10 years, principally because of the wider availability of education and the consequent increase in the proportion of mothers who received more schooling.

Few studies have been conducted in Brazil to evaluate adolescent childbearing across generations, particularly with a focus on evaluating the educational, sexual and reproductive trajectories of daughters and sons. Most such studies involving young men have been carried out in other countries. ${ }^{4,5}$ A notable exception, however, is the GRAVAD study (Adolescent Pregnancy: A Multicenter Study on Young Persons, Sexuality and Reproduction in Brazil), conducted in 2002 among young men and women living in three cities. ${ }^{21}$ Its objective was to reconstruct the sexual and reproductive trajectories of the respondents and, albeit indirectly, to obtain information on the reproductive history of the previous generation.

We used GRAVAD data in this study to investigate whether the risk of young women becoming pregnant-or of young men impregnating a partner-was associated with their mother's having had her first child before age 20 , and if so, to determine whether adolescents' education level played a role in this association.

\section{METHODS}

\section{Protocol}

The GRAVAD study collected data from 4,634 men and women aged 18-24. The study used a three-stage probabilistic selection process to ensure that the sample was representative of the general population in this age-group. The sample included about 1,500 subjects in each of three cities-Porto Alegre, Rio de Janeiro and Salvador; the desired sample size was based on existing estimates of the percentage of women who had ever been pregnant by age
18 or 19 (25\% and $35 \%$, respectively, in 1996). ${ }^{22}$ Of this full sample, $66 \%$ were aged $20-24$, and $11 \%$ of respondents in this age-group did not know their mother's age at her first birth. Hence, 2,701 respondents were included in the present study; younger subjects were excluded because they could still get pregnant by age 20 , the age at which the dependent variable was dichotomized.

To guarantee adequate geographic distribution in the first stage, a randomized sample was selected and stratified into census sectors, grouped into five strata according to mean income level and the education level of the head of the family. In the second stage, 33 homes in each sector were randomly selected from a list produced to identify the domiciles of young persons in the targeted age-group, considering the possibility of a loss to follow-up of $20 \%$. In the third stage, a young person was chosen from among all eligible individuals in the selected house; the individual whose birthday was the first in the year was selected, or in the case of identical dates, the individual whose name was first on an alphabetical list.

Data were obtained in private face-to-face interviews held in discreet locations, and without the presence of third parties older than four. We used a previously tested questionnaire that collected information on respondents' educational, employment, sexual and reproductive histories. Almost all of the interviewers were students or professionals in human sciences who were of an age similar to that of the subjects. All completed questionnaires were reviewed by the supervising team. Twenty percent of the questionnaires were randomly selected, and specific responses were verified by telephone or by returning to respondents' homes. Double data entry was performed using Epi Info software version 6.04b. STATA version 10 was used to allow for incorporation of sample design effects and the relative weights of sampling units.

\section{Measures}

The age at which a young woman first became pregnant was the dependent variable; for young men, the corresponding variable was their age when they first impregnated a partner. The age at which a respondent's mother had her first child was the principal independent variable. Both variables were dichotomized as younger than 20 years old and 20 or older. (Young men and women who had no previous history of pregnancy, including virgins, were assigned to the older group.) For descriptive purposes, we combined these dependent and independent variables to yield four categories: both respondent and mother younger than 20, mother younger than 20 and respondent 20 or older, mother 20 or older and respondent younger than 20 , and both 20 or older.

The following covariables were selected to evaluate possible effect modifiers and confounding factors: the young person's race or ethnicity (white, black, mixed race or Brazilian Indian); per capita monthly family income (categories based on the minimum salary at the time of study, $\mathrm{R} \$ 180$, about US\$65); parents' union status (living together, sepa- 
rated when child was 20 or older, separated when child was younger than 20 or never lived together); involvement of the respondent in domestic chores when aged 15-18 (responsible for most chores, divided equally with others, helped or had no obligations); paid employment for at least three months prior to turning 20 (yes or no); respondent received his or her first information on pregnancy or contraception from mother (yes or no); and respondent's and mother's education levels. Educational mobility was assessed by comparing respondents' education level with that of their mother; ${ }^{23}$ using the completion of primary education as a cutoff point, the three categories were downward or both with low education, upward, and both with high education. Finally, a school trajectory measure classified respondents into three categories: irregular with temporary dropout, irregular without temporary dropout (i.e., the student repeated a grade) and regular.

\section{Analysis}

First, respondents were classified by their adolescent pregnancy experience and their mothers' adolescent childbirth experience. Differences across the percentage distributions of respondents in the four respondent-mother age categories, by background characteristic, were tested for significance using Pearson's chi-square test with secondorder Rao-Scott correction (1984). ${ }^{24}$ For both daughters and sons, differences in the distributions of both agegroups were also tested separately for each corresponding maternal age-group. Next, a stratified analysis tested for potential effect modifiers and confounding factors on the principal association, yielding odds ratios.

Multivariable logistic regression analysis was used to assess associations between adolescent pregnancy and mother's age at first childbirth. Possible confounding effects were verified, and factors that altered the principal association by around $20 \%$ when removed from the saturated model were considered confounders; those that were not confirmed as confounders were excluded from the final model. Covariables identified in the stratified analysis as potential effect modifiers of the principal association were tested for confirmation. Therefore, an effect modifier was any factor that modified the association across levels of the main explanatory variable. These covariables were added in a stepwise manner to the regression analyses.

Diagnosis of the model was made according to goodness of fit (analysis of residues) using the F-adjusted mean residual test. ${ }^{25}$ Because this is a more recently developed test for complex data, the same models were generated without weighting the data (naive model) and assessed using the Hosmer-Lemeshow goodness-of-fit test. The entire analysis was conducted while taking the gender differences identified in previous analyses into consideration; ${ }^{17,23}$ therefore, separate models were created for men and women.

The study was approved by the internal review boards of the institutions involved. Participants signed an informed consent form prior to completing the questionnaire.

\section{RESULTS}

Fifty-three percent of respondents were female, $49 \%$ were black or of mixed race, and 35\% were very poor (per capita monthly family income less than $\mathrm{R} \$ 180$; not shown). Seventy-eight percent of respondents had completed primary school, whereas $44 \%$ of their mothers had not finished their primary education. Thirty percent of women reported having gotten pregnant before their 20th birthday, and $21 \%$ of men had been younger than 20 when they first impregnated a partner. In these subgroups, 34\% of the women and $31 \%$ of the men reported that their own mother had had her first child before she was 20. Twentynine percent of women who had had an adolescent pregnancy were cohabiting at the time, as were $12 \%$ of adolescent men whose partner had gotten pregnant. Among women who reported an adolescent pregnancy, $46 \%$ had remained in school during the pregnancy, 37\% had left school after getting pregnant and $17 \%$ had left school and then got pregnant. Similarly, among adolescent men whose partner had gotten pregnant, $42 \%$ had stayed in school during the pregnancy, $40 \%$ had left school after the pregnancy and 18\% had already left school.

When respondents' age at first pregnancy was compared with their mother's age when she first gave birth, the distribution of men and women among the four categories was similar. In 13\% of all mother-daughter pairs, the mother had had a birth and the daughter a pregnancy during adolescence; for mother-son pairs, this proportion was 10\% (Figure 1). In 21\% of mother-daughter and mother-son pairs, however, the mother had had an adolescent birth but the daughter or son had not had a pregnancy experience by age 20 . In contrast, in $15 \%$ of mother-daughter and $12 \%$ of mother-son pairs, the mother was at least 20 when she had her first birth, while the daughter or son experienced a pregnancy during adolescence. Finally, in 51\% of motherdaughter pairs and $57 \%$ of mother-son pairs, the mother

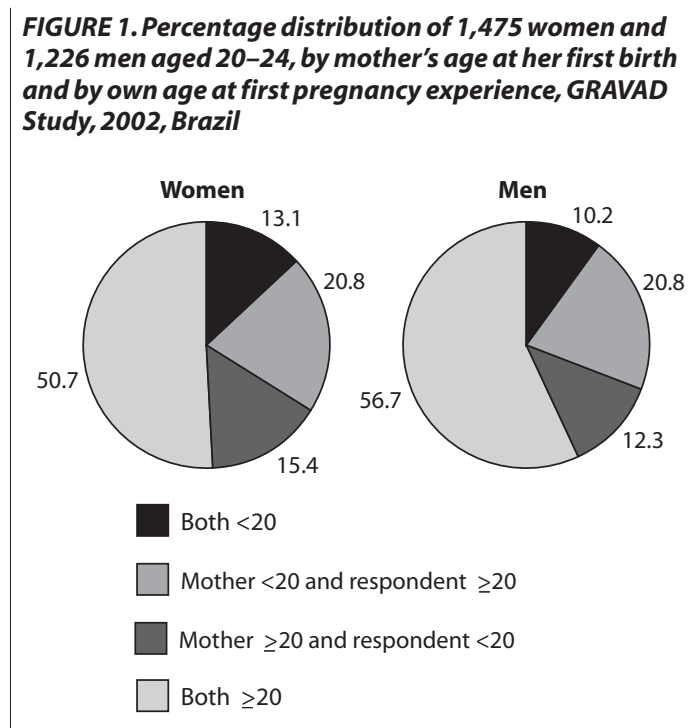

Note: Women who had not been pregnant, as well as men who had never impregnated a partner, were included in the older category. 
TABLE 1. Percentage distribution of men and women aged 20-24, by selected characteristics, according to mother's age at her first birth, daughter's age at first pregnancy and son's age at first pregnancy experience

\begin{tabular}{|c|c|c|c|c|c|c|c|c|c|c|}
\hline \multirow[t]{4}{*}{ Characteristic } & \multicolumn{4}{|c|}{ Mother's age at first birth } & \multirow[t]{4}{*}{ Total } & \multicolumn{4}{|c|}{ Mother's age at first birth } & \multirow[t]{3}{*}{ Total } \\
\hline & \multicolumn{2}{|l|}{$<20$} & \multicolumn{2}{|l|}{$\geq 20$} & & \multicolumn{2}{|l|}{$<20$} & \multicolumn{2}{|l|}{$\geq 20$} & \\
\hline & \multicolumn{4}{|c|}{ Daughter's age at first pregnancy } & & \multicolumn{4}{|c|}{ Son's age at first pregnancy experience } & \\
\hline & $<20$ & $\geq 20+$ & $<20$ & $\geq 20+$ & & $<20$ & $\geq 20 \neq$ & $<20$ & $\geq 20 \neq$ & \\
\hline & & & * & & & * & & * & & \\
\hline Race/ethnicity & $(\mathrm{N}=212)$ & $(\mathrm{N}=260)$ & $(\mathrm{N}=218)$ & $(\mathrm{N}=752)$ & $(\mathrm{N}=1,442)$ & $(\mathrm{N}=101)$ & $(\mathrm{N}=234)$ & $(\mathrm{N}=136)$ & $(\mathrm{N}=741)$ & $(\mathrm{N}=1,212)$ \\
\hline White & 37.6 & 28.5 & 36.6 & 58.6 & $46.4^{\circ}-x-10$ & 29.1 & 34.8 & 37.3 & 52.7 & 44.7 \\
\hline Mixed race & 25.7 & 30.2 & 30.6 & 18.8 & 23.8 & 19.1 & 31.8 & 14.3 & 27.5 & 25.9 \\
\hline Black & 28.1 & 29.3 & 25.7 & 18.8 & 23.2 & 47.6 & 23.6 & 37.9 & 15.1 & 23.0 \\
\hline Brazilian Indian & 8.6 & 11.9 & 7.1 & 3.8 & 6.6 & 4.2 & 9.8 & 10.5 & 4.7 & 6.4 \\
\hline Per capita monthly & * & & * & & & * & & * & & \\
\hline family income ( $\mathbf{R} \mathbf{S})$ & $(\mathrm{N}=215)$ & $(\mathrm{N}=270)$ & $(\mathrm{N}=222)$ & $(\mathrm{N}=768)$ & $(\mathrm{N}=1,475)$ & $(\mathrm{N}=102)$ & $(\mathrm{N}=237)$ & $(\mathrm{N}=138)$ & $(\mathrm{N}=749)$ & $(\mathrm{N}=1,226)$ \\
\hline$\leq 90$ & 33.8 & 15.9 & 26.1 & 7.2 & 15.4 & 27.0 & 12.5 & 20.9 & 6.7 & 11.7 \\
\hline $91-180$ & 34.3 & 21.7 & 25.0 & 16.3 & 21.1 & 32.9 & 16.8 & 20.5 & 11.9 & 16.1 \\
\hline $181-540$ & 29.3 & 48.1 & 34.0 & 34.4 & 36.5 & 29.2 & 52.7 & 34.8 & 42.5 & 42.3 \\
\hline \multirow[t]{2}{*}{$>540$} & 2.6 & 14.3 & 14.9 & 42.1 & 27.0 & 10.9 & 18.0 & 23.8 & 38.9 & 29.8 \\
\hline & \multicolumn{4}{|l|}{ * } & & & & & & \\
\hline Parents'status & $(\mathrm{N}=214)$ & $(\mathrm{N}=270)$ & $(\mathrm{N}=221)$ & $(\mathrm{N}=766)$ & $(\mathrm{N}=1,471)$ & $(\mathrm{N}=102)$ & $(\mathrm{N}=235)$ & $(\mathrm{N}=137)$ & $(\mathrm{N}=745)$ & $(\mathrm{N}=1,219)$ \\
\hline Living together & 46.4 & 64.1 & 60.1 & 71.8 & 65.1 & 54.5 & 51.5 & 62.4 & 68.7 & 62.9 \\
\hline Separated when child was $\geq 20$ & 1.1 & 1.9 & 2.3 & 3.0 & 2.4 & 0.2 & 2.6 & 2.9 & 4.3 & 3.3 \\
\hline Separated when child was $<20$ & 47.7 & 29.0 & 31.4 & 22.5 & 28.5 & 33.4 & 41.2 & 30.4 & 23.6 & 29.1 \\
\hline Never lived together & 4.8 & 5.0 & 6.2 & 2.7 & 4.0 & 11.9 & 4.7 & 4.3 & 3.4 & 4.6 \\
\hline Involvement in domestic & * & & * & & & & & & & \\
\hline chores when aged 15-18 & $(\mathrm{N}=212)$ & $(\mathrm{N}=270)$ & $(\mathrm{N}=220)$ & $(\mathrm{N}=765)$ & $(\mathrm{N}=1,467)$ & $(\mathrm{N}=99)$ & $(\mathrm{N}=236)$ & $(\mathrm{N}=137)$ & $(\mathrm{N}=749)$ & $(\mathrm{N}=1,221)$ \\
\hline Responsible for most chores & 36.0 & 16.8 & 27.5 & 6.4 & 15.7 & 10.6 & 3.0 & 2.3 & 3.3 & 3.8 \\
\hline Divided equally with others & 29.8 & 29.9 & 22.7 & 19.1 & 23.3 & 23.6 & 12.5 & 17.5 & 15.8 & 16.1 \\
\hline Helped & 28.1 & 42.5 & 41.2 & 50.7 & 44.6 & 41.8 & 48.9 & 49.2 & 47.0 & 47.2 \\
\hline Had no obligations & 6.2 & 10.7 & 8.6 & 23.8 & 16.4 & 24.0 & 35.6 & 31.0 & 33.9 & 32.9 \\
\hline Worked for $>3$ mos. & & & * & & & & & & & \\
\hline before age 20 & $(\mathrm{~N}=215)$ & $(\mathrm{N}=270)$ & $(\mathrm{N}=221)$ & $(\mathrm{N}=766)$ & $(\mathrm{N}=1,472)$ & $(\mathrm{N}=102)$ & $(\mathrm{N}=237)$ & $(\mathrm{N}=135)$ & $(\mathrm{N}=745)$ & $(\mathrm{N}=1,219)$ \\
\hline Yes & 66.1 & 67.6 & 65.5 & 56.1 & 61.3 & 86.3 & 78.3 & 86.4 & 71.4 & 76.2 \\
\hline No & 33.9 & 32.4 & 34.5 & 43.9 & 38.7 & 13.7 & 21.7 & 13.6 & 28.6 & 23.8 \\
\hline \multicolumn{6}{|l|}{ Received first information on } & & & & & \\
\hline from mother & $(N=214)$ & $(\mathrm{N}=270)$ & $(\mathrm{N}=222)$ & $(\mathrm{N}=768)$ & $(\mathrm{N}=1,474)$ & $(\mathrm{N}=101)$ & $(\mathrm{N}=236)$ & $(\mathrm{N}=137)$ & $(\mathrm{N}=748)$ & $(\mathrm{N}=1,222)$ \\
\hline Yes & 38.6 & 40.7 & 36.1 & 51.6 & 45.2 & 36.4 & 24.4 & 53.0 & 42.1 & 39.1 \\
\hline \multirow[t]{2}{*}{ No } & 61.4 & 59.3 & 63.9 & 48.4 & 54.8 & 63.6 & 75.6 & 47.0 & 57.9 & 60.9 \\
\hline & * & & * & & & * & & * & & \\
\hline Respondent's education level & $(\mathrm{N}=212)$ & $(\mathrm{N}=267)$ & $(\mathrm{N}=219)$ & $(\mathrm{N}=760)$ & $(\mathrm{N}=1,458)$ & $(\mathrm{N}=101)$ & $(\mathrm{N}=234)$ & $(\mathrm{N}=135)$ & $(\mathrm{N}=733)$ & $(\mathrm{N}=1,203)$ \\
\hline Did not finish primary & 43.9 & 14.2 & 30.9 & 3.9 & 15.5 & 53.6 & 30.4 & 28.0 & 10.4 & 21.2 \\
\hline Completed primary & 36.4 & 21.7 & 24.5 & 12.4 & 19.4 & 29.2 & 20.9 & 31.4 & 22.2 & 23.8 \\
\hline Attended high school/university & 19.7 & 64.1 & 44.6 & 83.7 & 65.2 & 17.2 & 48.7 & 40.6 & 67.4 & 55.0 \\
\hline & & & * & & & & & * & & \\
\hline Mother's education level & $(\mathrm{N}=199)$ & $(\mathrm{N}=264)$ & $(\mathrm{N}=219)$ & $(\mathrm{N}=760)$ & $(\mathrm{N}=1,445)$ & $(\mathrm{N}=96)$ & $(\mathrm{N}=222)$ & $(\mathrm{N}=131)$ & $(\mathrm{N}=741)$ & $(\mathrm{N}=1,190)$ \\
\hline Did not finish primary & 58.8 & 55.3 & 59.8 & 29.6 & 43.2 & 56.0 & 47.0 & 47.2 & 31.3 & 38.8 \\
\hline Completed primary & 25.0 & 18.0 & 19.6 & 18.0 & 19.1 & 15.5 & 23.2 & 23.6 & 19.9 & 20.6 \\
\hline Attended high school/university & 16.2 & 26.7 & 20.6 & 52.4 & 37.7 & 28.5 & 29.8 & 29.2 & 48.8 & 40.6 \\
\hline & * & & * & & & * & & * & & \\
\hline Educational mobility & $(\mathrm{N}=210)$ & $(\mathrm{N}=267)$ & $(\mathrm{N}=219)$ & $(\mathrm{N}=760)$ & $(\mathrm{N}=1,456)$ & $(\mathrm{N}=101)$ & $(N=234)$ & $(\mathrm{N}=135)$ & $(\mathrm{N}=733)$ & $(\mathrm{N}=1,203)$ \\
\hline Downward/low level & 80.2 & 35.9 & 55.4 & 16.3 & 34.8 & 82.8 & 51.3 & 59.4 & 32.6 & 45.0 \\
\hline Upward & 12.9 & 43.4 & 28.2 & 34.5 & 32.7 & 9.2 & 26.1 & 22.6 & 24.3 & 22.9 \\
\hline High level & 7.0 & 20.7 & 16.4 & 49.1 & 32.6 & 7.9 & 22.6 & 18.0 & 43.1 & 32.1 \\
\hline & * & & * & & & & & * & & \\
\hline School trajectory & $(\mathrm{N}=141)$ & $(\mathrm{N}=236)$ & $(\mathrm{N}=164)$ & $(\mathrm{N}=705)$ & $(\mathrm{N}=1,246)$ & $(\mathrm{N}=71)$ & $(\mathrm{N}=180)$ & $(\mathrm{N}=116)$ & $(\mathrm{N}=667)$ & $(\mathrm{N}=1,034)$ \\
\hline Irregular with temporary dropout & 73.5 & 43.0 & 56.7 & 18.0 & 34.5 & 70.0 & 58.6 & 56.8 & 33.3 & 44.5 \\
\hline Irregular without temporary & & & & & & & & & & \\
\hline dropout & 19.2 & 40.5 & 28.5 & 35.5 & 33.9 & 26.0 & 31.6 & 40.6 & 33.2 & 33.2 \\
\hline Regular & 7.3 & 16.5 & 14.8 & 46.5 & 31.6 & 4.0 & 9.8 & 2.6 & 33.5 & 22.3 \\
\hline Total & 100.0 & 100.0 & 100.0 & 100.0 & 100.0 & 100.0 & 100.0 & 100.0 & 100.0 & 100.0 \\
\hline
\end{tabular}

*Asterisks indicate that the distribution in the first column is significantly different from that in the second column, or that the distribution in the third column is significantly different from that in the fourth column, at $\mathrm{p}<.05$. IIncludes daughters who had not gotten pregnant. $\neq$ Includes sons who had never impregnated a partner. Note: Significant differences were found across the distributions of the four daughter-mother and four son-mother age categories for all variables. 
had not had an adolescent birth and the son or daughter had not experienced an adolescent pregnancy.

Among those whose mother had had her first child in adolescence, $61 \%$ of women did not get pregnant by age 20 and $67 \%$ of men said their partners had not become pregnant before they had turned 20, thereby not repeating their mothers' experience of early pregnancy (not shown). However, not all of the daughters' pregnancies-nor of the pregnancies among the sons' partners-led to childbirth: Eighty-four percent of pregnant daughters and $43 \%$ of sons' partners did not carry their pregnancies to term.

Among women whose mother had had an adolescent birth, higher proportions of those who had had an adolescent pregnancy than of those who had not were in the lowest two income tiers and had parents who had separated before the respondent was 20 (Table 1). They were more likely than their counterparts who had not become pregnant to have been responsible for most of the domestic chores, to have little education, to have had less education than their mother and to have attended school irregularly with temporary dropouts.

Women whose mother had had a child before age 20 but who themselves had not gotten pregnant by this age had higher family income than those who had had an adolescent pregnancy, and were more likely to have parents who stayed together and to have helped with household chores but not to be primarily responsible for them. The two groups reported similar levels of paid employment. Although more than half of young women without adolescent pregnancies had mothers who had not completed primary school, almost two-thirds had attended high school or university. In comparison with their peers who had become pregnant, they were more likely to have attended school irregularly without temporary dropout or to have attended regularly.

Among young women whose mother had not had an adolescent birth, those who had had an adolescent pregnancy were more likely than those who had not to come from a low-income family, to be black or of mixed race, and to have been principally responsible for household chores. Compared with their counterparts who had not had an early pregnancy, these young women were more likely to have worked for more than three months before they were 20 , and less likely to have received their first information on pregnancy and contraception from their mother. Like their mothers, more than half of this group had gone no further than primary school, and the majority had attended school irregularly, with temporary dropout.

Finally, women who, like their mothers, had delayed pregnancy and childbearing until after adolescence had the highest level of family income of the four groups; they were the least likely to have had the primary responsibility for chores and the least likely to have worked for more than three months before they were 20. These young women were the most likely of the four groups to have received their first reproductive health information from their mother. They were also the most likely to have a mother who had attended high school or university, and by far the most likely to have done so themselves.

Among men, the profiles across the four categories were similar to those among the women, with several exceptions. A majority of men had only helped with domestic chores or had no obligations between ages 15 and 18, and men were more likely than women to have worked in paid employment for more than three months prior to turning 20.

In the univariate logistic regression for women, adolescent pregnancy was associated with their mother's having had a child before age 20 (odds ratio, 2.0; Table 2). However, this association was lost once any responsibility for domestic chores at ages 15-18 (2.3) was added. The variable that had the strongest association with adolescent pregnancy when added to the model was women's not finishing or finishing only primary school (5.1), suggesting that this variable was the most important in the model.

In the logistic regression for men, being younger than 20 when they first impregnated a partner was associated with

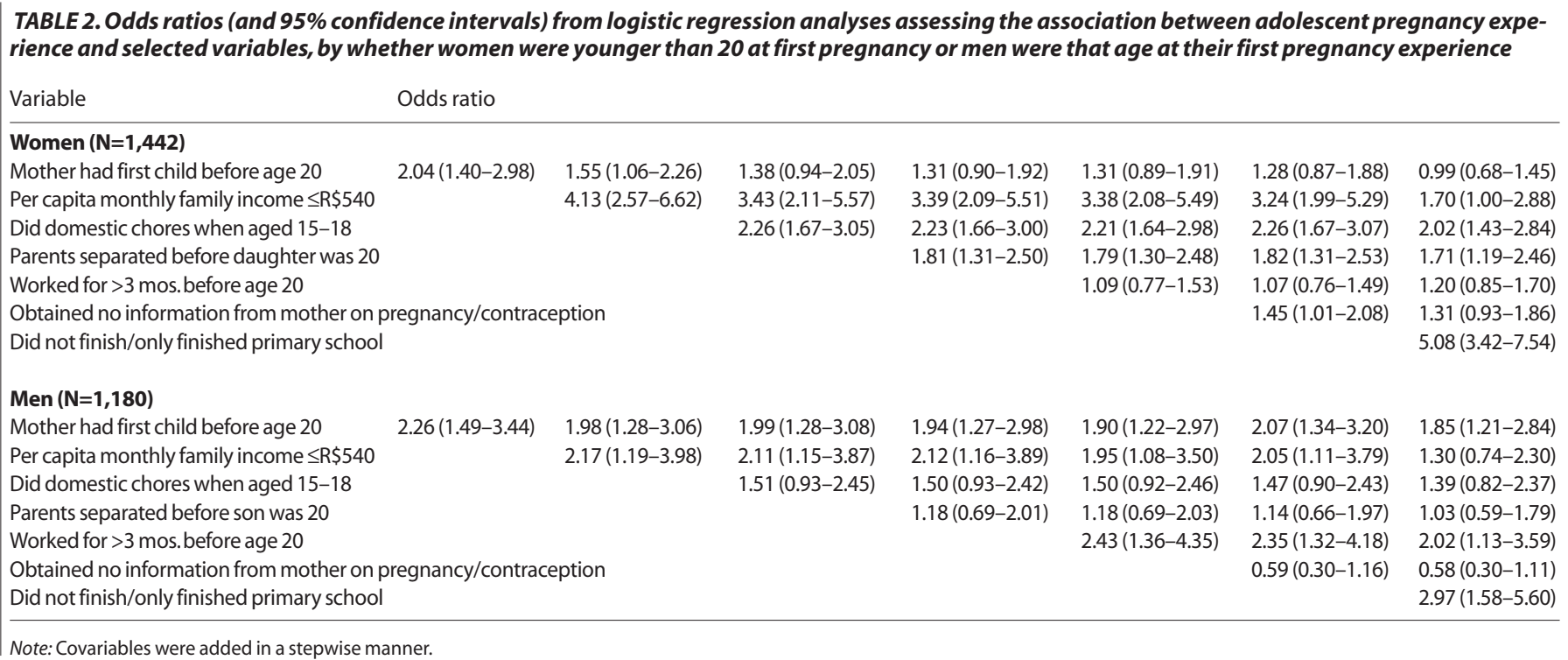


their mother's having given birth before age 20 (odds ratio, 2.3). The strength of this association generally decreased as the variables included in the women's analysis were added. However, unlike in the model for women, the mother's adolescent childbearing and the son being younger than 20 when his partner conceived remained associated, even with the inclusion of level of education in the model.

Following further analysis, we excluded all variables that did not act as effect modifiers or confounding factors, leaving only level of education in the final models on adolescent pregnancy for both men and women (not shown). For women, the positive association between having an adolescent pregnancy and their mother having her first child by age 20 disappeared when adjusted for her level of education (odds ratio, 1.27; 95\% confidence interval, 0.85-1.90). For men, however, being younger than 20 when they impregnated a partner and being the son of a woman who had had an adolescent birth remained associated when the education variable was added (1.76; 1.2-2.7).

\section{DISCUSSION}

Longitudinal studies are the most appropriate strategy for conducting intergenerational analyses, yet such studies are costly and protracted. Hence, we identified few studies of this type in the literature, and the majority of these originated in developed countries. One of the strengths of the GRAVAD study was the inclusion of data on the reproductive experience of the mothers of young men and women, which permitted analysis of the potential "transmission" of adolescent pregnancy across generations despite the cross-sectional design of the study.

The present study identified a crude association between daughters' and sons' level of education and their mother's early pregnancy. Nevertheless, this association diminished or disappeared when other variables were incorporated into the final regression models for men and women, respectively. Our results also demonstrated that there was considerable socioeconomic heterogeneity among the young men and women who experienced adolescent pregnancy. Nonetheless, the majority of these young people were of mixed race or black, and had low education levels and low family incomes. By contrast, the young people who, like their mother, delayed pregnancy and childbearing until after age 20 were predominantly white and had higher education levels and higher family incomes.

Similar findings have been reported in studies conducted in other countries. ${ }^{2-5}$ One of the studies suggested that the repetition of adolescent pregnancy across generations was influenced by the socioeconomic and environmental conditions in which the young people were raised, namely, low monthly family income, large families, low education levels and parents who were separated. ${ }^{5}$

However, because of gender differences and generational inequalities, caution should be exercised when comparing the reproductive experiences of mothers and sons. Only recently have men been included in studies of pregnancy before age 20, and therefore limited data are avail- able with which to assess generational differences. Furthermore, the fact that proportionally more men than women reported that their first experience of pregnancy occurred at age 20 or older reflects differences in the sexual and reproductive experiences of men and women. ${ }^{23}$

We found that sizable proportions of both men and women did not repeat their mother's experience of adolescent pregnancy, indicating that other factors may have played a role in their reproductive behavior. In the United States in the 1990s, ${ }^{1}$ it was already obvious that the large majority of daughters of black mothers who had had an early childbirth were not repeating the same pattern of parenthood. Furstenberg et al. ${ }^{1}$ believed that the legalization of abortion in the United States contributed toward the decline in births among adolescents, and allowed young people to make a choice about early child rearing. Although abortion is legally prohibited in Brazil, among the young people interviewed in the GRAVAD study, 17\% of adolescent women and $46 \%$ of adolescent men's partners terminated their pregnancy. ${ }^{26}$ This may be a reflection of their greater interest in academic pursuits, principally among individuals from the more privileged social classes who tend to delay first pregnancy or, in the case of an unplanned pregnancy, resort to induced abortion. According to that study, the proportion of abortions among first pregnancies grew as the level of schooling and family monthly per capita income increased. Furthermore, adolescent pregnancy was found to be less prevalent among more socially privileged young people, and when it did occur, they were more likely to opt for abortion. ${ }^{26}$

Although the cross-generational repetition of reproductive behavior was similar among women and men in our study and in the few other studies that have included men, ${ }^{4,5}$ the factors associated with this pattern were different for sons and daughters. In addition to education level, other factors related to adolescent pregnancy among women included performing domestic chores and the separation of parents before the child turned 20. For men, paid employment was the most important factor. Barber ${ }^{5}$ found that separation of parents was also related to the repetition of adolescent pregnancy and childbearing across generations.

Gender-related differences in the performance of domestic chores in adolescence merits particular mention. In general, surveyed women participated more in housework: The majority of those who became pregnant before age 20 and whose mothers had had their first child in adolescence were the principal persons responsible for domestic chores, suggesting that domestic responsibilities are a strong socialization mechanism promoting reproduction and maternity. Furthermore, given the risk of interruptions in education and dropping out of school, maternity may appear to be the only possible avenue that can be carried out successfully within unfavorable family and social contexts. ${ }^{27}$

Regardless of when their partner became pregnant, proportionally more men than women reported having worked for more than three months before age 20. Although there has been an increase in the participation of young women 
in the job market in recent decades, female participation is still lower than that of males, who become involved in economic activities even when they are still in school. ${ }^{28} \mathrm{Al}$ though increased access to the education system may improve men's and women's ability to enter the job market, women may still not be successful in obtaining better jobs or higher salaries, especially if they have children. ${ }^{29}$

Regarding the association of education level with adolescent pregnancy, the mean number of years of schooling completed by youth who began school between 1981 and 1985 (corresponding to those surveyed for this study) doubled the number of years completed by the generation that began school in 1941-1945, ${ }^{20}$ which may have contributed to our findings. Because the young people who were classified as upwardly mobile or at a high education level were also less likely than their mothers to have experienced adolescent pregnancy, it is reasonable to conclude that when younger generations have greater access to education, they also have improved opportunities to avoid early childbearing. Even with these opportunities, however, it is crucial to break the cycle of poverty that affects many young people in Brazil, which represents a significant barrier to their aspirations.

\section{Limitations}

This study has some limitations. The mother's age at the birth of her first child was supplied by her son or daughter, and their responses may not be accurate. Furthermore, about $10 \%$ of those interviewed were unable to supply this information; however, we found no differences between this group and the rest of the sample. Likewise, assuming that adolescent pregnancy would be a significant event in the lives of the young people (as well as in the lives of their mothers), if some responses were biased, the bias was probably toward underreporting their own pregnancy and that of their mother prior to age 20, which would have reduced the associations we found.

Another limitation is that young men may have underreported (or not known about) a partner's pregnancy, or a decision to have an abortion. Yet when women who said that they had become pregnant at some time were asked about their partner's reaction, only $2 \%$ said that he had not been told about it. ${ }^{30}$ Although these data were not included in the present study, it is reasonable to apply this information to the sample's population of men.

\section{Conclusions}

A positive association was found between the mother's age at her first childbirth and her daughter's or son's age at first pregnancy experience, as has been previously shown. ${ }^{1-4}$ Nevertheless, the most important finding was the role of the young adult's education level, which neutralized this association among women and diminished it among men.

These findings reinforce the need for policies aimed at increasing adolescents' access to schooling and encouraging them to remain in school, as well as helping those who have quit school to re-enroll. In addition, since gender differences and the cultural context in which young people live significantly shape their educational and reproductive trajectories, the health care system must define specific strategies to ensure that young women and men are provided with adequate information on contraceptive methods, which would help enable them to make informed choices and thus postpone the start of their reproductive lives.

\section{REFERENCES}

1. Furstenberg FF, Jr., Levine JA and Brooks-Gunn J, The children of teenage mothers: patterns of early childbearing in two generations, Family Planning Perspectives, 1990, 22(2):54-61.

2. Kahn JR and Anderson KE, Intergenerational patterns of teenage fertility, Demography, 1992, 29(1):39-57.

3. Manlove J, Early motherhood in an intergenerational perspective: the experiences of a British cohort, Journal of Marriage and the Family, 1997, 59(22):263-279.

4. Hardy JB et al., Like mother, like child: intergenerational patterns of age at first birth and associations with childhood and adolescent characteristics and adult outcomes in the second generation, Developmental Psychology, 1998, 34(6):1220-1232.

5. Barber J, The intergenerational transmission of age at first birth among married and unmarried men and women, Social Science Research, 2001, 30(2):219-247.

6. Pouta A et al., Mothers and daughters: intergenerational patterns of reproduction, European Journal of Public Health, 2005, 15(2):195-199.

7. Campa MI and Eckenrode JJ, Pathways to intergenerational adolescent childbearing in a high-risk sample, Journal of Marriage and Family, 2006, 68(3):558-572.

8. East PL, Reyes BT and Horn EJ, Association between adolescent pregnancy and a family history of teenage births, Perspectives on Sexual and Reproductive Health, 2007, 39(2):108-115.

9. Madeira FR, Education and inequality in the time of youth, in: Camarano AA, ed., Transition to Adulthood or Adulthood in Transition? Rio de Janeiro, Brazil: Institute of Applied Economic Research, 2006, pp. 139-169 (in Portuguese).

10. Fujimori E et al., Perfil socioeconomico y biologico de embarazadas adolescentes de una maternidade de beneficencia en São Paulo, Brasil, Cuadernos Médico Sociales, 1997, 38(2):97-104.

11. Gupta N and Leite IC, Trends and determinants of fertility among adolescents in northeastern Brazil, Perspectivas Internacionais de Planejamento Familiar, 2001, (special number):24-29 \& 45 (in Portuguese).

12. Sabroza AR et al., A socioeconomic and psychosocial profile of post-partum adolescence in the city of Rio de Janeiro, Brazil, 1999-2001, Cadernos de Saúde Pública, 2004, 20(Suppl. 1):S112-S120 (in Portuguese).

13. Chalem E et al., Teenage pregnancy: behavioral and socio-demographic profile of an urban Brazilian population, Cadernos de Saúde Pública, 2007, 23(1):177-186 (in Portuguese).

14. Berquó E, Brazil, an exemplary case-contraception and surgical births-waiting for an exemplary action, Revista Estudos Feministas, 1993, 1(2):367-381 (in Portuguese).

15. Berquó E and Cavenaghi S, Fertility in decline: a brief note on the reduction in the average number of children per woman in Brazil, Novos Estudos, 2006, 74:11-15 (in Portuguese)

16. Berquó E and Cavenaghi S, Mapping socioeconomic and demographic regimes of fertility in Brazil and its variation between 1991 and 2000, paper presented at the XIV National Meeting of Population Studies, Caxambu, Minas Gerais, Brazil, Sept. 20-24, 2004 (in Portuguese)

17. Brandão ER et al., Youth and family: preliminary reflections on teenage pregnancy in the urban middle class, Interseções: Revista de Estudos Interdisciplinares, 2001, 3(2):159-180 (in Portuguese).

18. Almeida MCC, Aquino EML and Barros AP, School trajectory and teenage pregnancy in three Brazilian state capitals, Cadernos de Saúde Pública, 2006, 22(7):1421-1430.

19. Heilborn ML and Cabral CS, Juvenile parenthood: condensed transition to adulthood, in: Camarano AA, ed., Transition to Adulthood or 
Adulthood in Transition? Rio de Janeiro, Brazil: Institute of Applied Economic Research, 2006, pp. 225-253 (in Portuguese).

20. Rios-Neto ELG, César CC and Riani JLR, Educational stratification and progression by grade school in Brazil, Pesquisa e Planejamento Econômico, 2003, 32(3):395-416 (in Portuguese)

21. Heilborn ML et al., Learning Sexuality: Reproduction and Social Trajectories Among Young People in Brazil, Rio de Janeiro, Brazil: Fiocruz/ Garamond, 2006 (in Portuguese).

22. Civil Society for Family Welfare in Brazil (BEMFAM) et al., Brazil Demographic and Health Survey, 1996, Rio de Janeiro, Brazil: BEMFAM; and Calverton, MD, USA: Macro International, 1997 (in Portuguese).

23. Bozon M, Characteristics of the population researched, in: Heilborn ML et al., eds., Learning Sexuality: Reproduction and Social Trajectories Among Young People in Brazil, Rio de Janeiro, Brazil: Fiocruz/Garamond, 2006, pp. 137-154 (in Portuguese).

24. StataCorp, Stata Statistical Software, Release 10, College Station, TX, USA: StataCorp, 2007

25. Archer KJ, Lemeshow S and Hosmer DW, Goodness-of-fit tests for logistic regression models when data are collected using a complex sampling design, Computational Statistics \& Data Analysis, 2007. 5l(9):4450-4464.

26. Menezes GMS, Aquino EML and Silva DO, Induced abortion during youth: social inequalities in the outcome of the first pregnancy, Cadernos de Saúde Pública, 2006, 22(7):1431-1446.

27. Stern $C$ and Medina G, Adolescence and health in Mexico, in: Oliveira MC, ed., Culture, Adolescence and Health: Argentina, Brazil, México, Campinas, Brazil: Consortium Programs in Reproductive Health and Sexuality in Latin America, 2000, pp. 98-160 (in Portuguese).

28. Camarano AA, Transition to adulthood: changes by period and cohort, in: Camarano AA, ed., Transition to Adulthood or Adulthood in Transition? Rio de Janeiro, Brazil: Institute of Applied Economic Research, 2006, pp. 95-135 (in Portuguese).

29. Rosemberg F, Formal education, women and gender relationships: preliminary assessment to 90 , in: Bruschini $C$ and Unbehaum SG, eds., Gender, Democracy and Brazilian Society, São Paulo, Brazil: Editora 34, 2002, pp. 195-224 (in Portuguese)

30. Aquino EML, Almeida MCC and Menezes G, Teenage pregnancy: the heterogeneity revealed, in: Heilborn ML et al., eds., Learning Sexuality: Reproduction and Social Trajectories Among Young People in Brazil, Rio de Janeiro, Brazil: Fiocruz/Garamond, 2006, pp. 309-360 (in Portuguese).

\section{RESUMEN}

Contexto: El embarazo durante la adolescencia se ha asociado con la experiencia de la maternidad temprana de las madres de los y las adolescentes; y se considera el nivel educativo de la gente joven como un factor importante en este fenómeno. Métodos: En 2002, una encuesta representativa de hogares recolectó datos de 3,050 hombres y mujeres jóvenes de 20-24 años en tres ciudades brasileñas. Las principales medidas fueron la edad de la madre de los encuestados en el momento de su primer parto, la edad de la joven en el primer embarazo y la edad del joven al embarazar por primera vez a una pareja; los grupos de edad se dividieron en menores de 20 y de 20 años o mayores. La distribución de las personas encuestadas (tanto por su propia experiencia reproductiva como la de su madre), se analizó en relación con varias características, y se valoró mediante regresiones logísticas las posibles asociaciones entre estas variables y la experiencia del embarazo.

Resultados: Treinta por ciento de las jóvenes reportaron haberse embarazado antes de los 20 años; y 21\% de los hombres dijeron que eran menores de 20 años cuando su pareja se embarazó. De estos grupos, 34\% de las mujeres y 31\% de los hombres reportaron que sus madres habian dado a luz por prime- ra vez a la misma edad. Tanto las mujeres como los hombres tuvieron mayor probabilidad de experimentar un embarazo temprano si su madre había tenido un hijo antes de los 20 años (razones de momios, 2.0 y 2.3, respectivamente). En las mujeres, esta asociación positiva desapareció en el modelo final, después de ajustar por nivel de educación, mientras que entre los hombres la asociación permaneció después de un ajuste similar (1.8).

Conclusiones: El nivel de educación de las hijas e hijos parece ser un factor importante en la repetición de la fecundidad adolescente a través de las generaciones. Se necesita esfuerzos para aumentar el acceso a la educación y para alentar a la gente joven a que permanezca en la escuela.

\section{RÉSUMÉ}

Contexte: Les grossesses d'adolescentes ont été associées à l'expérience de la maternité précoce des mères des adolescents concernés et le niveau d'instruction des jeunes semble jouer un rôle important.

Méthodes: En 2002, une enquête de ménages représentative a recueilli des données auprès de 3.050 jeunes hommes et femmes de 20 à 24 ans dans trois villes du Brésil. Les principales mesures ont porté sur l'âge de la mère à la première naissance, l'âge de la fille à la première grossesse et l'âge du fils au moment de la fécondation d'une partenaire. Les âges ont été dichotomisés entre moins de 20 ans et 20 ans ou plus. La distribution des répondants en fonction de leur propre expérience génésique et de celle de leur mère a été analysée selon différentes caractéristiques, tandis que les associations possibles entre ces variables et l'expérience d'une grossesse étaient évaluées par régressions logistiques.

Résultats: Trente pour cent des femmes ont déclaré avoir été enceintes avant l'âge de 20 ans, tandis que 21\% des hommes déclaraient avoir eu moins de 20 ans au moment de la fécondation de leur partenaire. De ces groupes, 34\% des femmes et $31 \%$ des hommes ont déclaré que leur mère avait accouché pour la première fois à ce même âge. Tant les femmes que les hommes sont apparus plus susceptibles d'avoir connu une grossesse précoce si leur mère avait eu un enfant avant l'âge de 20 ans (rapports de probabilités, 2,0 et 2,3, respectivement). Côté féminin, cette association positive disparaît dans le modèle final après correction du niveau d'instruction; côté masculin, elle se maintient après correction similaire $(1,8)$.

Conclusions: Le niveau d'instruction des filles comme des fils semble jouer un rôle important dans la répétition de la fécondité adolescente d'une génération à l'autre. Des efforts sont nécessaires pour accroître l'accès à l'éducation et encourager les jeunes à poursuivre leur scolarisation.

\section{Acknowledgments}

The authors thank the GRAVAD team, especially the principal investigators Maria Luiza Heilborn, Michel Bozon and Daniela Knauth. We acknowledge the support of the Ford Foundation, the National Council of Scientific Development and Technology, Brazil, and the Committee for Postgraduate Courses in Higher Education, Brazil.

Author contact: conceicao@bahia.fiocruz.br 